\title{
A Gathering of Eagles
}

Andrew D. Saal, MD

"Let me get this straight," I sighed with a smile twisted by irony. "You did what?" The old man repeated his story for my disbelief. Outside the emergency department window crimson twilight played on the high cliffs surrounding the hospital. The sun drifted to sleep while the moon rose to stand watch over this little corner of the Hopi Reservation in northern Arizona.

It was my turn on call for the night. I swung the overhead surgical light around to get a better look at the Hopi elder's scalp. A modest V-shaped gash adorned his head above his right ear. "So, please tell me how you managed to do this.... This I've got to hear."

The old man laughed. $\mathrm{He}$, too, in retrospect was incredulous. With a partially toothless grin, he chuckled and offered me more details. He and several members of his extended clan had gone out to the buttes for religious reasons. "And then this rock fell on my head." He finished speaking almost as quickly as he had started. Silence again filled the examination room.

"Am I missing something here?" I humbly apologized and asked for just a few more details of the accident. "You don't have to describe any of the ceremonies," I said, trying to be culturally sensitive. "But I do need to figure out the mechanism of the injury."

He laughed again with his big bearlike voice. "Ceremony? Heck no. We were only gathering eagles ...." The elder was somewhere in his mid70 , but the twinkle in his eyes hinted at his youthfulness. One of his Hopi duties was to obtain eagle feathers and eaglets for their ceremonies. Once a year in the late spring, he and a few of his clan would journey to the buttes on the edge of the reservation.

“The paperwork's the real killer." He chuckled,

Submitted 23 September 1997.

From the Keams Canyon Hospital, US Indian Health Service, Keams Canyon, Arizona. Address reprint requests to Andrew D. Saal, MD, PO Box 579, Keams Canyon, AZ 86034. recounting the reams of forms that he had to fill out before each annual excursion. The buttes were on the joint-use lands between the Hopi and Navajo nations. "That triples the bureaucratic mess." It didn't surprise me that this government boarding school graduate knew the word "bureaucratic" intimately. After notifying two federal agencies and both the Navajo and Hopi rangers, the elderly man and his colleagues had started out on their annual pilgrimage.

The lonely butte soared several hundred feet above the desert plains. Several clusters of eagles dwelled in the crags and ledges of the stony monolith. From below, the men staked out the nests with binoculars and patience. When all was ready, they said a prayer and started up toward the summit. The narrow unmarked trail twisted among giant sandstone boulders and ancient lava flows. Slowly but steadily the small party began to wind its way up the slope. The old man and the other elders had laughed as the younger clan members lost their footing on the slick loose gravel.

The trail disappeared into a wall of stone. The Hopi elders scrambled up about 10 feet onto an overhanging ledge with a lifetime of familiarity. With quiet reverence, the party had stopped its joking and started the actual climbing into the aerie of the eagles. The ceremonial hunt had begun.

The old man let the story hang in the air unfinished. He understood the fine art of storytelling, and I was like a grandchild on his knee. When I could no longer stand the silence, I finally spoke up, playing the role of the rapt child. "So what went wrong? Did you get tired and slip? Was there some kind of accident?"

"Heck no!" he laughed out loud. "I'm not that old yet! I'm only in my 70s. Besides, we left my old uncle at the foot of the cliff in the shade." He smiled as he continued with his tale. My imagination painted a sweeping panorama of the massive butte with small specks of color on the cliff walls 
halfway up. The old man and his friends reached up for the next handhold and the higher ledge.

Scrambling up boulders, crevasses, and along precipitous drops, the small party of Hopi cliff climbers ascended several hundred feet using only a short piece of rope. No hammers, pitons, or pulleys. And no helmets. Brilliant white cumulus clouds sailed high overhead in the seas of blue Arizona sky. Behind them, the hundred-mile horizon defined infinity. Far off, the three Hopi mesas, their traditional home, stretched southward from the mammoth Black Mesa. An early summer breeze tickled their skin as they rested beneath the final ledge that led to the summit.

An ancient lava flow had covered the sandstone here. With its hard cap of stone, the butte had slowly emerged from the desert. The surrounding unprotected sandstone had slowly been eroded away by eons of wind and water. The rocky cliffs of the butte had stood silent guard over the millennia.

"We were right there, just below the summit." After a moment of silent reflection, he laughed about the entire mishap and continued his story. Standing on a narrow ledge several hundred feet up in the sky, my 70-something-year-old patient tried to boost one of the younger men up to reach the final overhang. "He did it, too," he exclaimed, after elaborating on his superhuman feat of physical strength for several heart-wrenching moments. "All he had to do was lower the rope."

The Hopi elder stopped again, letting the drama of his tale permeate the air. This master storyteller was savoring every second of my anticipation.

My brain was spinning with hundreds of possibilities, each one more catastrophic than the last. What could have possibly thwarted these stalwart mountaineers of the Southwest?

"And ....?" I finally asked, seeking the climax to finish the tale.

"And what?" he replied. "The fool knocked a small rock loose, and it hit me just like this." He reached over and smacked me benevolently on the side of my head. He was thoroughly enjoying the telling of the story more than he had of the actual event. The old man chuckled about his last tap against my slow-learning skull. Any Hopi child would have been prepared for such a playful ending to a grandfather's tale.

"So just when did this accident happen?"

"Oh, about 8 AM or so."

"You mean you spent the entire day scaling cliffs and swinging from a rope?!"

"Of course. I'm not that old yet. Besides, my hair stopped the oozing." His long jet-black hair was tied back in a ponytail. The taut fibers had mixed with the blood to create a Band-Aid of sorts.

"Well, what did you do that high up on the cliff face?" I inquired. "Did you black out or have any weakness or double vision?"

"What did I do? Well, I finished gathering the eagles, of course. I didn't fill out all those forms and kiss the Navajo rangers' butts for nothing." His laughter rolled through the room like warm summer thunder. I was slowly beginning to understand. "I filled my quota too!" Humble pride radiated from his grandfatherly countenance. And after hearing his tale of adventure, I finally had to agree with him.

"You're right," I commented, "You're only as old as you feel, and you've obviously lost all sense of feeling." He howled again with a hearty laugh.

After 10 sutures, a tetanus shot, and some ibuprofen, he gathered his belongings to leave. $\mathrm{He}$ punched me playfully in the arm as he headed for the door. "I can't wait until next year's gathering," he laughed as he disappeared into the night.

Somewhere, deep inside, memories of my own stirred. For a few fleeting moments, I could have sworn that my own grandfather had just been in the room with me. 